\title{
BENEFIT FROM CHAINED MASONRY WALLS TO IMPROVE THE SEISMIC RESPONSE OF REINFORCED CONCRETE BUILDINGS
}

\author{
Abdelkader Nour ${ }^{1}$, Abdelkader Benanane ${ }^{1}$ and Humberto Varum ${ }^{2}$ \\ 1. Laboratory Materials and Processes of Construction, Faculty of Science \& \\ Technology, University of Mostaganem, Algeria; abdelkader.nour@univ-mosta- \\ $d z$, abdelkader.benanane@univ-mosta-dz
}

2. CONSTRUCT-LESE, Department of Civil Engineering, Faculty of Engineering, University of Porto, Portugal; hvarum@fe.up.pt

\begin{abstract}
The multiple earthquakes have proved the effect of chained masonry walls on the seismic behaviour of multistorey reinforced concrete buildings. The chained masonry walls have been considered one of the types of masonry infill walls but without gaps between the wall and the surrounding frame. This participation came intending to study this effect through the modeling of several two-dimensional frames for a multistorey reinforced concrete building, taking into account the hollow brick walls, which represent the most common type in Algeria. We analyzed the proposed models using ETABS finite element software, relying on the response spectrum method and respecting the most important requirements according to the applicable Algerian Seismic Code. After analysis of the different models, the results have been compared according to the parameters of the period, base shear, lateral displacement, and stiffness. Through a critical synthesis of the results, we concluded that these walls could significantly affect the seismic behaviour of this type of buildings. Moreover, the neglect of these walls in the modeling process can lead designers to have a false perception of the behaviour of these buildings towards seismic loadings.
\end{abstract}

\section{KEYWORDS}

Chained masonry wall, Seismic behaviour, Reinforced concrete building, Hollow brick, Algerian Seismic Code

\section{INTRODUCTION}

The need to infill the spaces between columns and beams, is a necessary issue in building and construction processes, especially in multi-storey buildings, this type of building is widely used in most parts of the world, especially in Algeria. Also, the most well-known types of infill walls are those which are mainly made of hollow red bricks due to their lightness and multiple properties.

Based on the multiple earthquakes that have hit various parts of the world, it can be said that these have caused severe damage to these types of buildings and caused many of them to collapse completely.

If we looked at the direct causes of these earthquakes, we would find that they do not deviate from two basic questions:

First, it is necessary to ensure the proper design of buildings to be constructed by finding models that simulate the actual behaviour of buildings when exposed to potential earthquakes. This allows us to reduce the damage that these inevitable disasters can cause. 


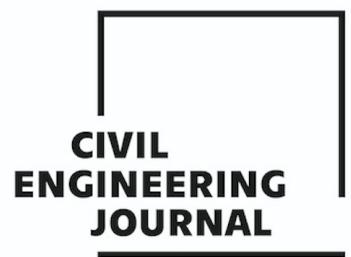

Article no. 33

THE CIVIL ENGINEERING JOURNAL 2-2021

Secondly, the strict implementation of the previously prepared designs, ensuring that the appropriate materials are brought in for the construction operations, and continuous monitoring of the work to ensure that the completed buildings conform to what was designed.

To shine more light and scrutinize, we have tried to address the first reason, which revolves around the following question: how to achieve the best simulation of what will be accomplished in the site?

To answer this question, we can say that the only way to achieve this is to try to model the largest possible number of constituent elements of this building, taking into account the importance and behaviour of each component to know its role in strength or rigidity.

In addition to what will be detailed in this article, masonry infill walls, cannot be neglected in the analysis of reinforced concrete or steel buildings, nor be considered as non-structural elements, because the reality lies and the best proof of all that we have said is the loss and damage, which has been recorded across different countries.

In an attempt to understand the behaviour of these walls, we have listed the most important approaches used in the structural analysis of reinforced concrete buildings, which were the results of the most important research and experiments based on real models or scaled-down models.

These approaches can be summarized in three main families, which are simplistic models (macro-models) [1-3], average models (meso-models) [3-7], as well as precise models (micromodels) [1-5,8-10]. To highlight evidence of this diversity, we can say that it results from the different characteristics of the different components of these masonry walls without forgetting the interaction between them and the surrounding environment [3-5,11-13].

Following the Boumerdes earthquake on May 21, 2003, and at the invitation of Mr. Mohamed Nadir HAMIMIDE, Minister of Housing and Urban Planning, Mr. Victor DAVIDOVICI went to Algeria from Wednesday, May 28 to Sunday, June 1, 2003 [19].

The objective of this mission was to make an independent analysis of the causes of the multiple damages and collapses of buildings and to propose priority actions to be put in place in the immediate [19].

Through this mission, this researcher drew up a preliminary report, where he tried to present the most important reasons that caused, in one way or another, the collapse of important parts of the buildings that were subjected to the earthquake, and he focused on particular on the walls of the masonry infill most used in our country, which builds walls and connects them rigidly to the frames that surround it (Figure 1 \& Figure 2) [19]. This article has therefore focused on this particular type, which represents the most responded type in Algeria and hence the term chained masonry which has been used in this article.

Although the Algerian seismic code [17] does not give any method to model masonry infill walls, this earthquake engineering consultant also explained that not modeling these walls in the design processes causes the building to lose additional stiffness and resistance. This led us to think about presenting a reliable model on this aspect, through which we can treat the seismic behaviour of these infill walls. 


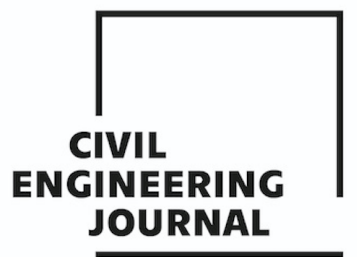

Article no. 33

THE CIVIL ENGINEERING JOURNAL 2-2021

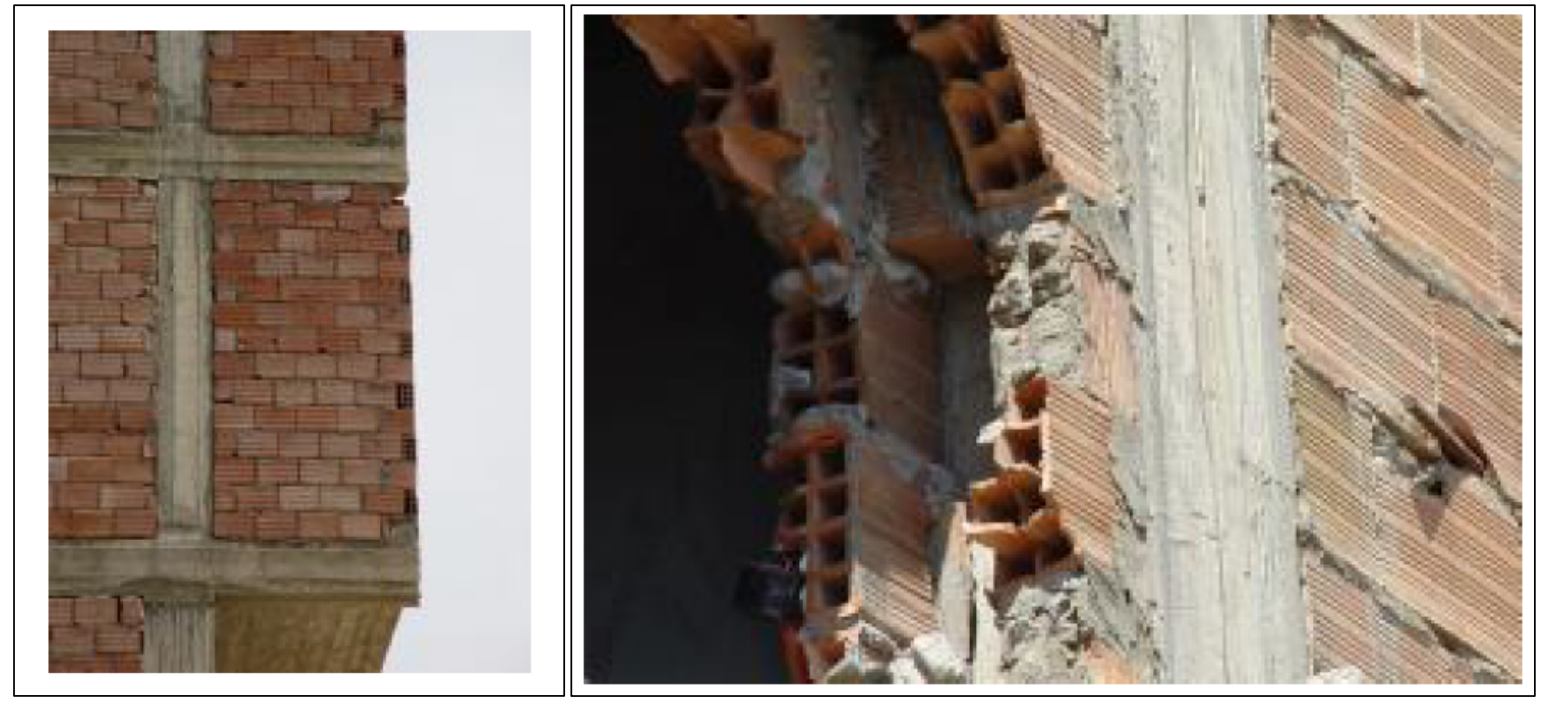

Fig. 1 - Rigid connection, BOUMERDES earthquake of May 21, 2003

The subject of the study that we will present below is limited to the importance of the role played by the chained masonry wall. This type represents the case of masonry infill without gaps, either with the columns or with the beams, in hollow bricks interconnected by a cement-based mortar, these walls occupy the void for the reinforced concrete frame in high seismicity area, according to the current codes in Algeria [14].

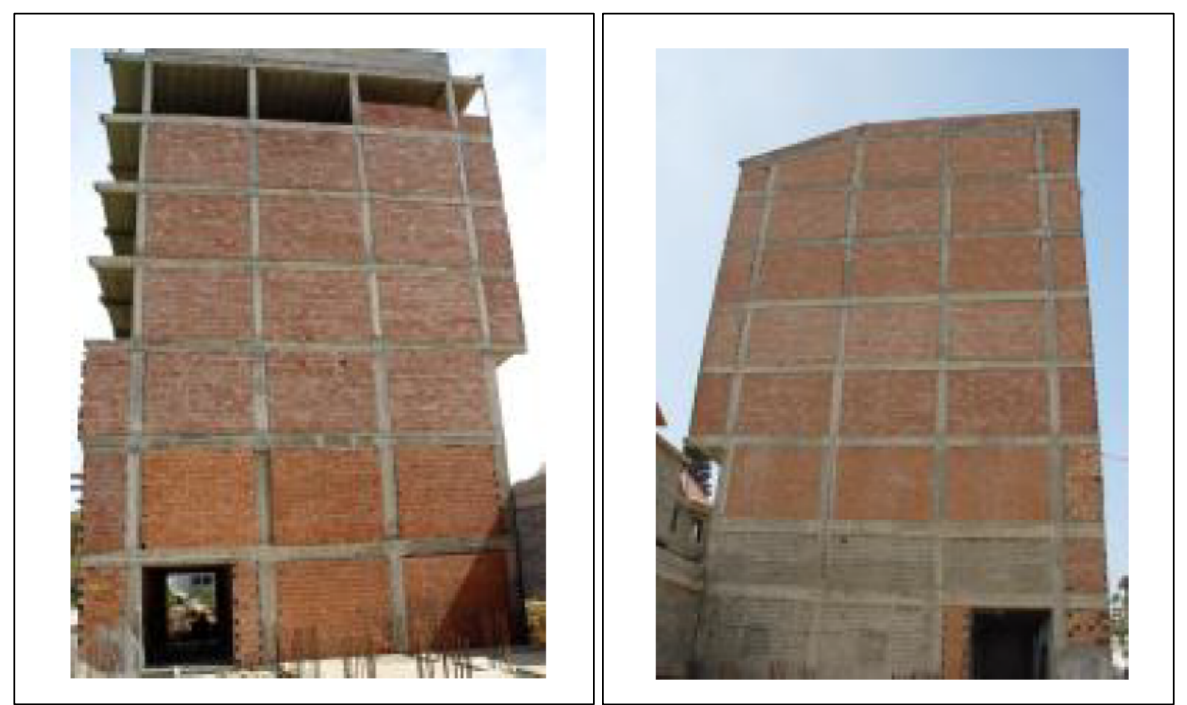

Fig. 2 - Chained masonry, BOUMERDES earthquake of May 21, 2003

In the following, we have carried out a parametric study by analyzing several models of a two-dimensional multistorey reinforced concrete frame using the response spectrum method.

With ETABS finite element software [15], we analyzed the proposed models and compared the results by a critical synthesis to assess the seismic response of these models by the study of the positive role paled by the chained masonry infill walls. 
Article no. 33

CIVIL

ENGINEERING

JOURNAL

THE CIVIL ENGINEERING JOURNAL 2-2021

\section{METHODS}

The study presented in this article concerns the numerical modeling of $2 \mathrm{D}$ reinforced concrete frames, using ETABS software [15], by the response spectrum method recommended in the Algerian Seismic Code (ASC99v2003) [17].

The analysis of the models is summarized as follows:

Modeling the frames and extracting the results for the period, base shear, lateral displacement, and stiffness, so this is a linear dynamic analysis.

\section{Presentation of the analyzed models}

The span lengths are $3.00,4.50,6.00$, and $7.50 \mathrm{~m}$ and the number of spans is 2,4 , and 6 for all models. The number of storeys is fixed at 11 storeys and the storey height is $3.06 \mathrm{~m}$.

The characteristics of concrete and steel of columns and beams are taken from the Algerian Code of Reinforced Concrete [16]. The compressive strength of concrete is $25000 \mathrm{kN} / \mathrm{m}^{2}$, the elastic limit of steel is $500000 \mathrm{kN} / \mathrm{m}^{2}$.

The masonry used in this study is the hollow brick cited in the Algerian Code of Masonry [14], with an elastic modulus of $2000000 \mathrm{kN} / \mathrm{m}^{2}$, and compressive strength of $2000 \mathrm{kN} / \mathrm{m}^{2}$. The wall thickness of the chained masonry is $0.30 \mathrm{~m}$, which represents a double leaf wall, with a bloc of $0.10 \mathrm{~m}$, bloc of $0.15 \mathrm{~m}$, and $0.05 \mathrm{~m}$ of space between two pieces of hollow bricks as shown in Table 1.

Tab. 1 - Geometric and mechanical characteristics of frames

\begin{tabular}{|c|c|}
\hline Designation & Values or type \\
\hline Concrete strength $\left(\mathrm{kN} / \mathrm{m}^{2}\right)$ & 25000 \\
\hline Modulus of elasticity of concrete, $\mathrm{E}_{\mathrm{c}}\left(\mathrm{kN} / \mathrm{m}^{2}\right)$ & 32164000 \\
\hline Steel tensile yield strength $\left(\mathrm{kN} / \mathrm{m}^{2}\right)$ & 500000 \\
\hline Storey height $(\mathrm{m})$ & 3.06 \\
\hline Number of storey & 11 \\
\hline Building height $(\mathrm{m})$ & $33.66 \mathrm{~m}$ \\
\hline Span length $(\mathrm{m})$ & $3.00 \mathrm{~m}, 4.50 \mathrm{~m}, 6.00 \mathrm{~m}$ and $7.00 \mathrm{~m}$ \\
\hline Number of spans & 2,4 and 6 \\
\hline Masonry compressive strength, $\mathrm{f}_{\mathrm{m}}\left(\mathrm{kN} / \mathrm{m}^{2}\right)$ & 2000 \\
\hline Modulus of elasticity of masonry, $\mathrm{E}_{\mathrm{m}}\left(\mathrm{kN} / \mathrm{m}^{2}\right)$ & 2000000 \\
\hline Thickness of masonry walls, $\mathrm{t}_{\mathrm{m}}(\mathrm{m})$ & 0.30 \\
\hline
\end{tabular}

The cross-sections of columns and beams are grouped in Table 2.

Tab. 2 - Cross-sections of beams and columns

\begin{tabular}{|c|c|c|c|c|}
\hline \multirow{5}{*}{ Number of storey } & \multicolumn{4}{|c|}{ Length Span $(\mathrm{m})$} \\
\hline & $3.00 \mathrm{~m}$ & $4.50 \mathrm{~m}$ & $6.00 \mathrm{~m}$ & $7.50 \mathrm{~m}$ \\
\hline & \multicolumn{4}{|c|}{ Beam's Dimensions (m) } \\
\hline & $0.30 \times 0.30$ & $0.30 \times 0.40$ & $0.30 \times 0.50$ & $0.30 \times 0.60$ \\
\hline & \multicolumn{4}{|c|}{ Column's Dimensions (m) } \\
\hline 11 & \multicolumn{4}{|c|}{$0.45 \times 0.45$} \\
\hline 10 & \multicolumn{4}{|c|}{$0.45 \times 0.45$} \\
\hline 9 & \multicolumn{4}{|c|}{$0.50 \times 0.50$} \\
\hline 8 & \multicolumn{4}{|c|}{$0.50 \times 0.50$} \\
\hline 7 & \multicolumn{4}{|c|}{$0.50 \times 0.50$} \\
\hline 6 & \multicolumn{4}{|c|}{$0.55 \times 0.55$} \\
\hline 5 & \multicolumn{4}{|c|}{$0.55 \times 0.55$} \\
\hline 4 & \multicolumn{4}{|c|}{$0.55 \times 0.55$} \\
\hline 3 & \multicolumn{4}{|c|}{$0.60 \times 0.60$} \\
\hline 2 & \multicolumn{4}{|c|}{$0.60 \times 0.60$} \\
\hline 1 & \multicolumn{4}{|c|}{$0.60 \times 0.60$} \\
\hline
\end{tabular}


For the loads used in the analysis of all frames, we have $6 \mathrm{kN} / \mathrm{m}^{2}$ as dead loads and $1.50 \mathrm{kN} / \mathrm{m}^{2}$ as live loads.

For the response spectrum, we referred to the Algerian Seismic Code (ASC99v2003) [17], by using a spectrum for a zone of high seismicity (zone III), a user group of 2, a loose soil (S3), and a behaviour factor of 3.5 .

For the source of the mass, we took the totality of the dead loads plus $20 \%$ of the live loads [17].

\section{Validation of the proposed model}

For the validation of the proposed model, we used the famous SEISMOSTRUCT software [18], which offers a great possibility of modeling the masonry infill walls, of a 7-storey frame, and then we compared the results with the use of the ETABS software of the same frame mentioned above [15].

The model of Seismostruct software, has validated experimentally. In Seismostruct software, the infill is considered as a four-node masonry panel element developed and initially programmed by Crisafulli (1997) [..] and implemented in Seismostruct by Blandon (2005) to see the nonlinear response of infill panels in frames. Each panel is represented by six struts; each diagonal direction represents two struts capable of taking axial loads along two opposite diagonal corners and a third to take shear from the top to the bottom of the panel. This last link acts only across the diagonal which is in compression, therefore it's (activation) depends on the deformation of the infill panel. The connecting strut under axial loads use the hysteresis model of masonry connecting struts developed by Crisafulli et all (2000) [..].

\section{RESULTS}

In this section, we proceeded to compare, comment, and discuss the results according to the period, the base shear, the lateral displacement, and stiffness.

\section{Comparison of analyzed models in term of period}

Tab. 3- Period of analyzed frames

\begin{tabular}{|c|c|c|c|c|c|c|c|c|c|c|c|c|}
\hline \multirow{2}{*}{$\begin{array}{c}\text { Number } \\
\text { of } \\
\text { spans }\end{array}$} & \multicolumn{3}{|c|}{ Span length $(3.00 \mathrm{~m})$} & \multicolumn{3}{|c|}{ Span length $(4.50 \mathrm{~m})$} & \multicolumn{3}{|c|}{ Span length $(6.00 \mathrm{~m})$} & \multicolumn{3}{|c|}{ Span length $(7.50 \mathrm{~m})$} \\
\hline & $\begin{array}{c}\text { Bare } \\
\text { Frame }\end{array}$ & $\begin{array}{l}\text { Fully } \\
\text { Infilled }\end{array}$ & $\begin{array}{c}\text { Ratio } \\
(\%)\end{array}$ & $\begin{array}{c}\text { Bare } \\
\text { Frame }\end{array}$ & $\begin{array}{l}\text { Fully } \\
\text { Infilled }\end{array}$ & $\begin{array}{c}\text { Ratio } \\
(\%)\end{array}$ & $\begin{array}{l}\text { Bare } \\
\text { Frame }\end{array}$ & $\begin{array}{l}\text { Fully } \\
\text { Infilled }\end{array}$ & $\begin{array}{c}\text { Ratio } \\
(\%)\end{array}$ & $\begin{array}{c}\text { Bare } \\
\text { Frame }\end{array}$ & $\begin{array}{l}\text { Fully } \\
\text { Infilled }\end{array}$ & $\begin{array}{c}\text { Ratio } \\
(\%)\end{array}$ \\
\hline 2 & 1.485 & 0.589 & $60.34 \%$ & 1.456 & 0.538 & $63.05 \%$ & 1.427 & 0.514 & $63.98 \%$ & 1.405 & 0.501 & $64.34 \%$ \\
\hline 4 & 1.457 & 0.487 & $66.58 \%$ & 1.446 & 0.471 & $67.43 \%$ & 1.427 & 0.465 & $67.41 \%$ & 1.413 & 0.462 & $67.30 \%$ \\
\hline 6 & 1.448 & 0.454 & $68.65 \%$ & 1.442 & 0.451 & $68.72 \%$ & 1.427 & 0.450 & $68.47 \%$ & 1.416 & 0.451 & $68.15 \%$ \\
\hline \multicolumn{13}{|c|}{ Used unit in Seconds } \\
\hline
\end{tabular}




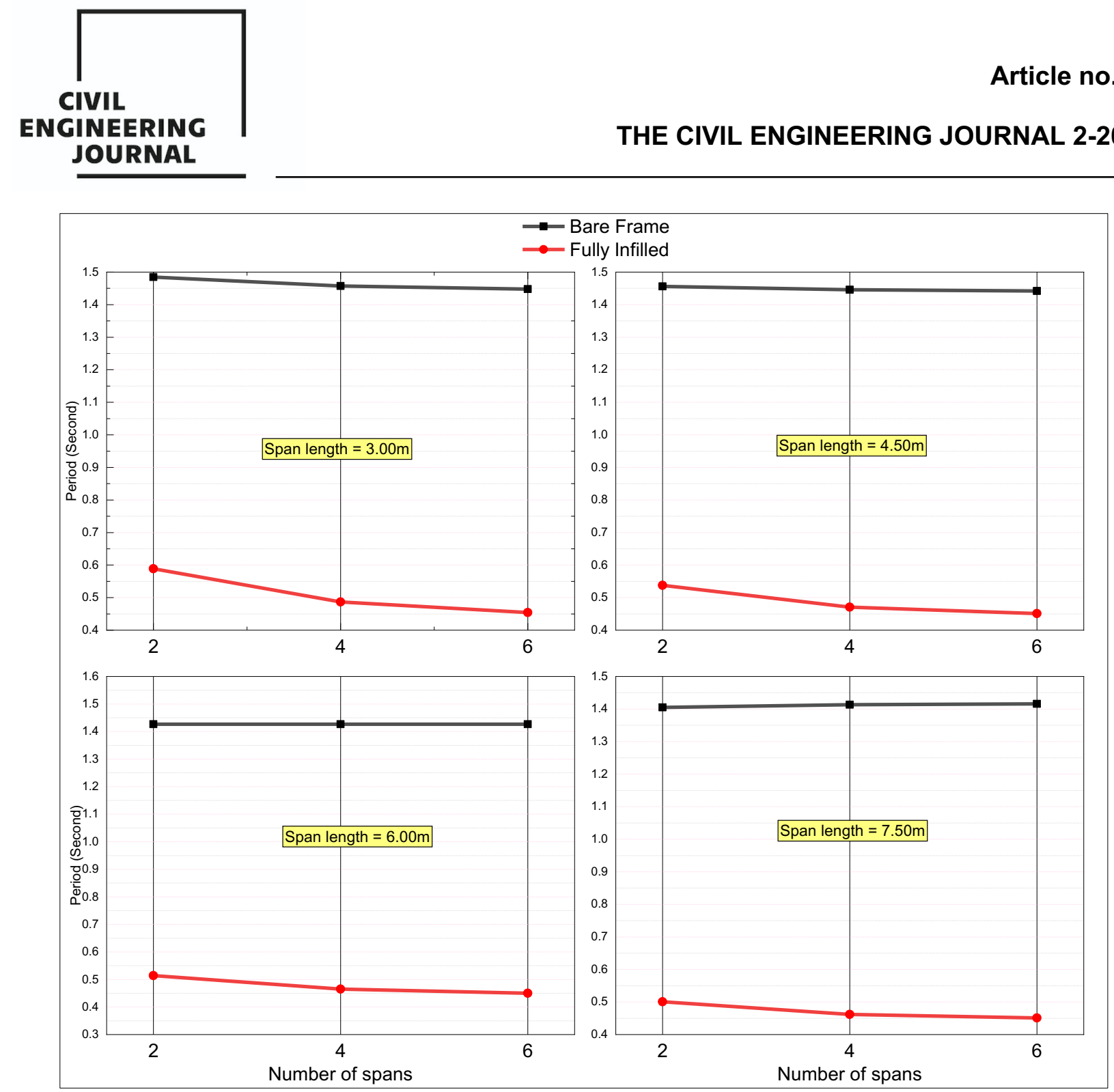

Fig. 3 - Period of analyzed frames

Table 3 and Figure 3 represent the comparison of the results between the different models that were analyzed in terms of the period of vibration, which can be summarized as follows:

This allows us to notice that all fully infilled frames recorded much lower period values than their fully bare counterparts, indicating that the introduction of chained masonry infill walls in the modeling processes of reinforced concrete frames, has significantly contributed to the decrease in period values and thus helps these frames exhibit better strength to seismic loadings.

If we want to deepen the analysis of the results obtained, we can say that the values of the period of all models fully infilled frames, decreased by more than $60 \%$ compared to their fully bare counterparts.

These significant values recorded by all fully infilled frames undoubtedly demonstrated the significant contribution of chained masonry infill walls to improving the performance of these frames when exposed to seismic loadings. 


\section{Comparison of analyzed models in term of base shear}

\begin{tabular}{|c|c|c|c|c|c|c|c|c|c|c|c|c|}
\hline \multirow{2}{*}{$\begin{array}{c}\text { Number } \\
\text { of } \\
\text { spans }\end{array}$} & \multicolumn{3}{|c|}{ Span length $(3.00 \mathrm{~m})$} & \multicolumn{3}{|c|}{ Span length $(4.50 \mathrm{~m})$} & \multicolumn{3}{|c|}{ Span length $(6.00 \mathrm{~m})$} & \multicolumn{3}{|c|}{ Span length $(7.50 \mathrm{~m})$} \\
\hline & $\begin{array}{l}\text { Bare } \\
\text { Frame }\end{array}$ & $\begin{array}{l}\text { Fully } \\
\text { Infilled }\end{array}$ & $\begin{array}{c}\text { Ratio } \\
(\%)\end{array}$ & $\begin{array}{l}\text { Bare } \\
\text { Frame }\end{array}$ & $\begin{array}{l}\text { Fully } \\
\text { Infilled }\end{array}$ & $\begin{array}{c}\text { Ratio } \\
(\%)\end{array}$ & $\begin{array}{l}\text { Bare } \\
\text { Frame }\end{array}$ & $\begin{array}{l}\text { Fully } \\
\text { Infilled }\end{array}$ & $\begin{array}{c}\text { Ratio } \\
(\%)\end{array}$ & $\begin{array}{l}\text { Bare } \\
\text { Frame }\end{array}$ & $\begin{array}{l}\text { Fully } \\
\text { Infilled }\end{array}$ & $\begin{array}{c}\text { Ratio } \\
(\%)\end{array}$ \\
\hline 2 & 191.18 & 376.52 & 1.97 & 272.66 & 577.01 & 2.12 & 361.59 & 785.84 & 2.17 & 454.91 & 1003.95 & 2.21 \\
\hline 4 & 371.16 & 848.59 & 2.29 & 532.95 & 1263.20 & 2.37 & 707.50 & 1691.14 & 2.39 & 891.26 & 2132.80 & 2.39 \\
\hline 6 & 552.15 & 1337.98 & 2.42 & 791.36 & 1956.15 & 2.47 & 1053.37 & 2596.26 & 2.46 & 1324.90 & 3257.49 & 2.46 \\
\hline
\end{tabular}

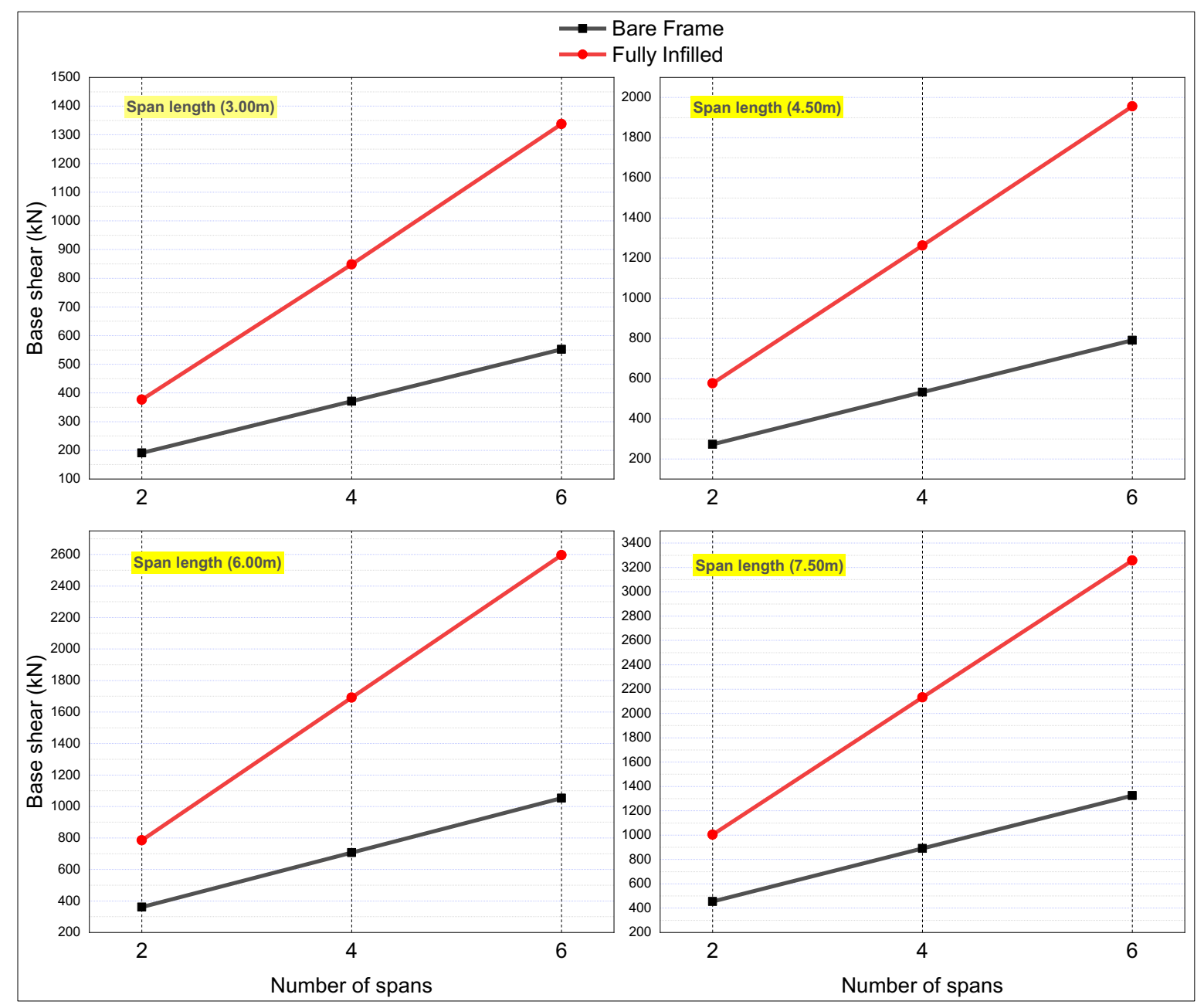

Fig. 4 - Base shear of analyzed frames

Table 4 and Figure 4 summarize the results of the different models that had analyzed in terms of the base shear, which can be interpreted as follows:

These results allow us to note that all fully infilled frames had recorded much larger base shear values than their fully bare counterparts. This comes down to the consideration of the chained masonry infill walls by their inclusion in the modeling of the reinforced concrete frames, which participated significantly in the increase of the basic shear values and therefore increases the strength of these frames to seismic loadings. 
If we want to detail the analysis of the aforementioned results, we can say that the base shear values of all models of fully infilled frames have increased by more than 2 times compared to their fully bare counterparts.

These significant values recorded by all fully infilled frames demonstrated the important contribution of chained masonry infill walls to improving the performance of these frames when exposed to seismic loadings.

\section{Comparison of analyzed models in term of lateral displacement}

Tab. 5 - Lateral displacement of analyzed frames

\begin{tabular}{|c|c|c|c|c|c|c|c|c|c|c|c|c|}
\hline \multirow{2}{*}{$\begin{array}{c}\text { Number } \\
\text { of } \\
\text { spans }\end{array}$} & \multicolumn{3}{|c|}{ Span length $(3.00 \mathrm{~m})$} & \multicolumn{3}{|c|}{ Span length $(4.50 \mathrm{~m})$} & \multicolumn{3}{|c|}{ Span length $(6.00 \mathrm{~m})$} & \multicolumn{3}{|c|}{ Span length $(7.50 \mathrm{~m})$} \\
\hline & $\begin{array}{l}\text { Bare } \\
\text { Frame }\end{array}$ & $\begin{array}{l}\text { Fully } \\
\text { Infilled }\end{array}$ & $\begin{array}{c}\text { Ratio } \\
(\%)\end{array}$ & $\begin{array}{l}\text { Bare } \\
\text { Frame }\end{array}$ & $\begin{array}{l}\text { Fully } \\
\text { Infilled }\end{array}$ & $\begin{array}{c}\text { Ratio } \\
(\%)\end{array}$ & $\begin{array}{l}\text { Bare } \\
\text { Frame }\end{array}$ & $\begin{array}{l}\text { Fully } \\
\text { Infilled }\end{array}$ & $\begin{array}{c}\text { Ratio } \\
(\%)\end{array}$ & $\begin{array}{l}\text { Bare } \\
\text { Frame }\end{array}$ & $\begin{array}{l}\text { Fully } \\
\text { Infilled }\end{array}$ & $\begin{array}{c}\text { Ratio } \\
(\%)\end{array}$ \\
\hline 2 & 0.0710 & 0.0224 & $68.45 \%$ & 0.0682 & 0.0194 & $71.55 \%$ & 0.0661 & 0.0179 & $72.92 \%$ & 0.0646 & 0.0170 & $73.68 \%$ \\
\hline 4 & 0.0683 & 0.0167 & $75.55 \%$ & 0.0671 & 0.0158 & $76.45 \%$ & 0.0658 & 0.0151 & $77.05 \%$ & 0.0648 & 0.0148 & $77.16 \%$ \\
\hline 6 & 0.0677 & 0.0148 & $78.14 \%$ & 0.0666 & 0.0144 & $78.38 \%$ & 0.0657 & 0.0142 & $78.39 \%$ & 0.0649 & 0.0141 & $78.27 \%$ \\
\hline
\end{tabular}
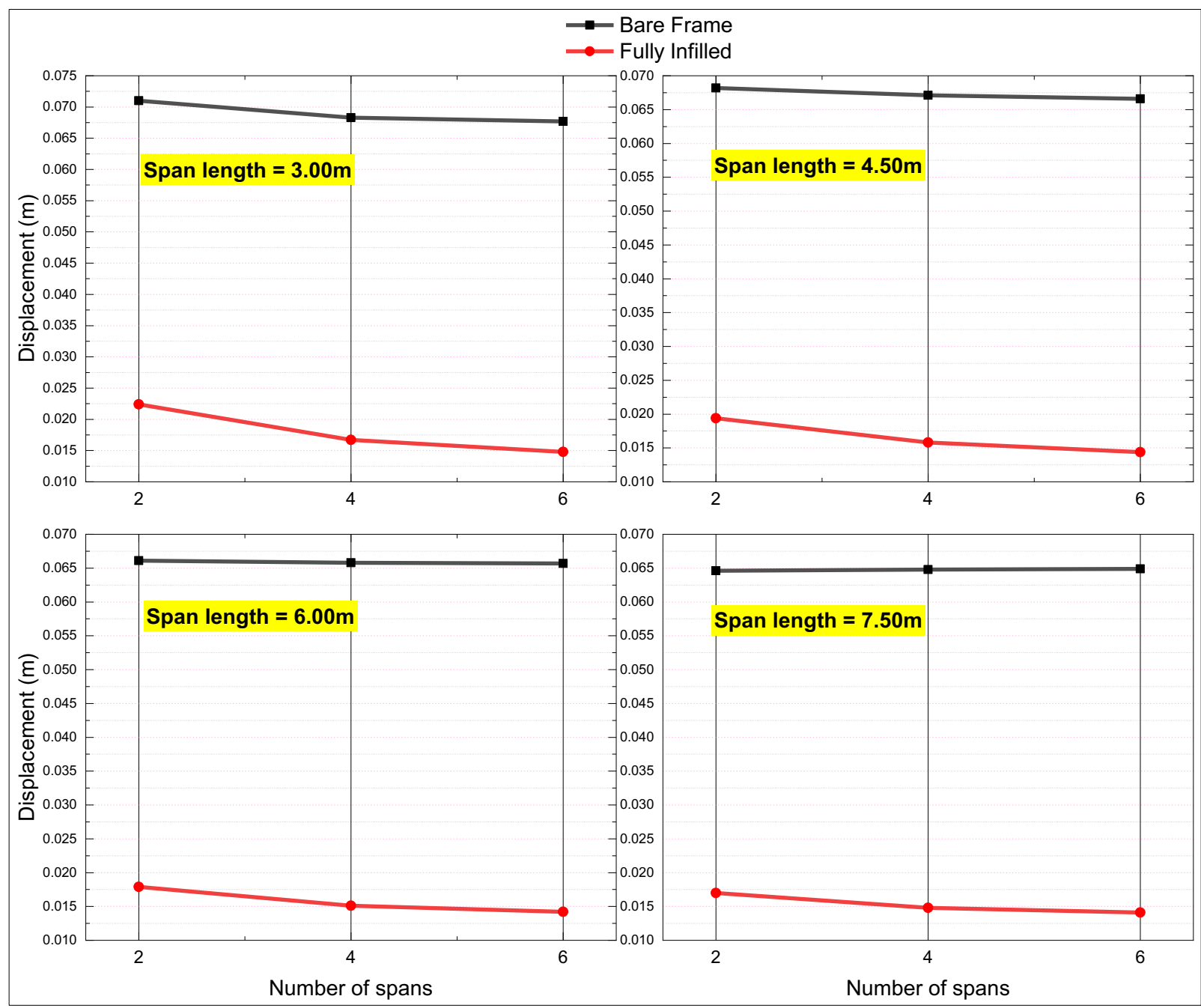

Fig. 5 - Lateral displacement of analyzed frames 
Through Table 5 and Figure 5, which represent the results obtained within the framework of the analysis of the seismic response in terms of the lateral displacement of the reinforced concrete frames, we can read the following:

All fully infilled frames recorded small values compared to their fully bare counterparts. This decrease in the lateral displacement values is the result of the introduction of chained masonry infill walls, in the modeling processes of the reinforced concrete frames that have been proposed.

These results can be detailed by reading the percentages, which have been recorded in the table above, where we can notice that all the percentages varied between $68 \%$ and $78 \%$, which are important percentages, which cannot be neglected and which have indicated the great change in seismic behaviour of these frames. This leads us to say that the inclusion of these walls in the modeling process can play a vital role in improving the strength of reinforced concrete buildings when they are exposed to seismic loadings.

\section{Comparison of analyzed models in term of stiffness}

Tab. 6 - Stiffness of analyzed frames

\begin{tabular}{|c|c|c|c|c|c|c|c|c|c|c|c|c|}
\hline \multirow{2}{*}{$\begin{array}{c}\text { Number } \\
\text { of } \\
\text { spans }\end{array}$} & \multicolumn{3}{|c|}{ Span length $(3.00 \mathrm{~m})$} & \multicolumn{3}{|c|}{ Span length $(4.50 \mathrm{~m})$} & \multicolumn{3}{|c|}{ Span length $(6.00 \mathrm{~m})$} & \multicolumn{3}{|c|}{ Span length $(7.50 \mathrm{~m})$} \\
\hline & $\begin{array}{l}\text { Bare } \\
\text { Frame }\end{array}$ & $\begin{array}{l}\text { Fully } \\
\text { Infilled }\end{array}$ & $\begin{array}{c}\text { Ratio } \\
(\%)\end{array}$ & $\begin{array}{l}\text { Bare } \\
\text { Frame }\end{array}$ & $\begin{array}{l}\text { Fully } \\
\text { Infilled }\end{array}$ & $\begin{array}{c}\text { Ratio } \\
(\%)\end{array}$ & $\begin{array}{l}\text { Bare } \\
\text { Frame }\end{array}$ & $\begin{array}{l}\text { Fully } \\
\text { Infilled }\end{array}$ & $\begin{array}{l}\text { Ratio } \\
(\%)\end{array}$ & $\begin{array}{l}\text { Bare } \\
\text { Frame }\end{array}$ & $\begin{array}{l}\text { Fully } \\
\text { Infilled }\end{array}$ & $\begin{array}{l}\text { Ratio } \\
(\%)\end{array}$ \\
\hline 2 & 63490 & 348824 & 5.49 & 81177 & 475040 & 5.85 & 99541 & 598909 & 6.02 & 117996 & 721909 & 6.12 \\
\hline 4 & 117440 & 724729 & 6.17 & 150066 & 961867 & 6.41 & 183734 & 1200600 & 6.53 & 217288 & 1440452 & 6.63 \\
\hline 6 & 170975 & 1099107 & 6.43 & 218558 & 1447250 & 6.62 & 267613 & 1801793 & 6.73 & 316207 & 2159438 & 6.83 \\
\hline
\end{tabular}




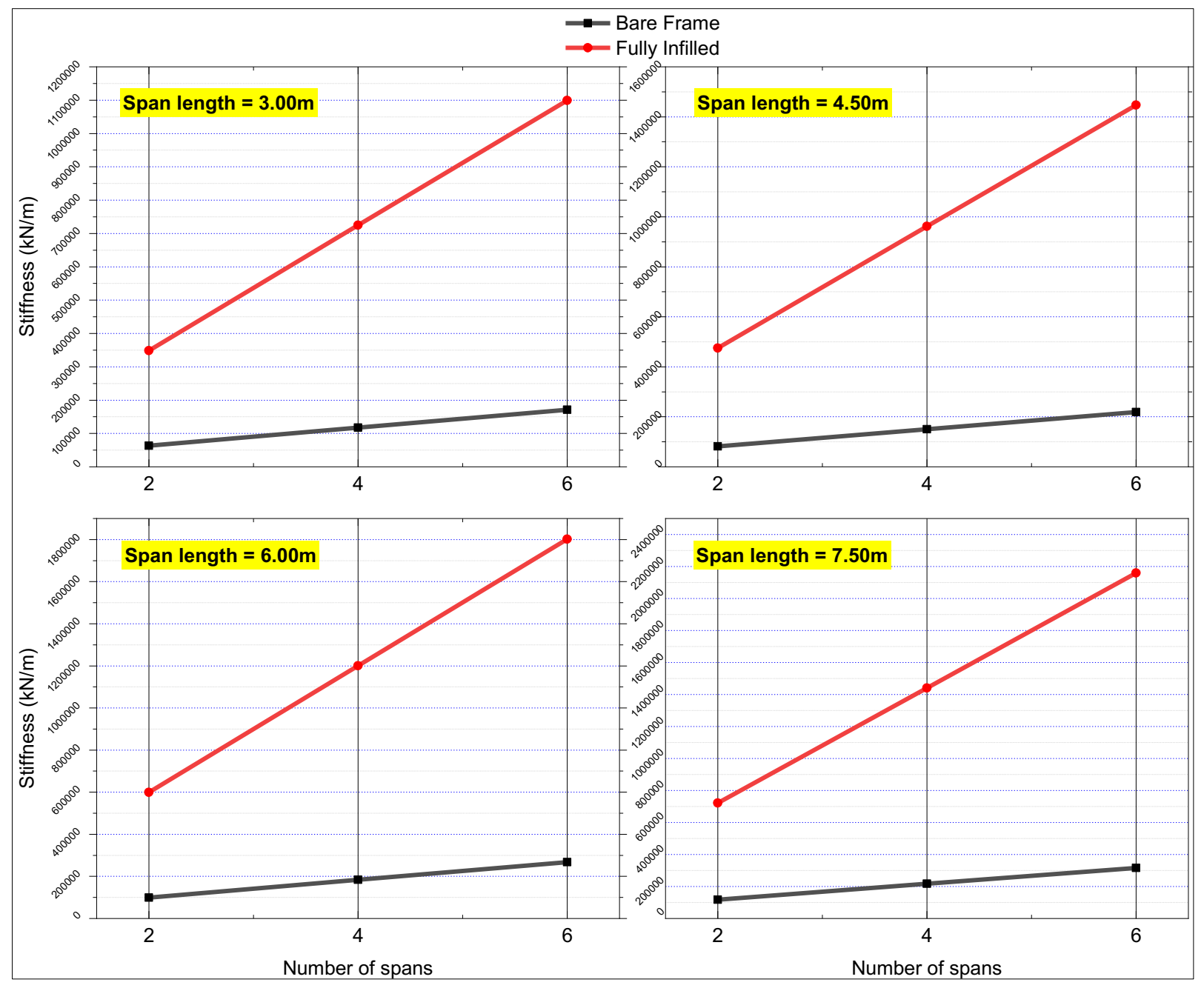

Fig. 6 - Stiffness of analyzed frames

From Figure 6 and also from Table 6, one can quite easily read the large values of the stiffness parameter recorded by all fully infilled frames, compared to fully bare frames, and this is mainly due to the presence of chained masonry infill walls, in the modeling process of reinforced concrete frames.

From the results presented in the table above, it is noted that all the fully infilled frames have stiffness values between 5 and 6 times compared to the values given by their fully bare counterparts.

The results obtained have proven to us beyond any reasonable doubt that the direct modeling of these chained masonry walls has greatly contributed to improving the seismic performance of reinforced concrete frames and significantly increased the strength of these frames when they are exposed to seismic loadings.

\section{CONCLUSION}

After completing the study of the proposed models, as well as the results and comparisons according to the parameters that we have previously identified, we can draw the following conclusions:

The direct introduction of chained masonry infill walls, like the main element in the modeling process of reinforced concrete frames, has greatly contributed to lowering the values of the period as well as the lateral displacement and increased the values of the base shear and stiffness. This 


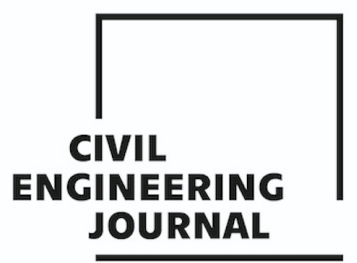

Article no. 33

\section{THE CIVIL ENGINEERING JOURNAL 2-2021}

allows these frames to acquire better strength to seismic loadings and consequently improves the seismic performance of this type of buildings.

Through the previous results, we can see the essential impact that these walls left on the seismic response of reinforced concrete buildings.

The indirect inclusion of these walls, or their neglect in the process of modeling of reinforced concrete buildings, may lead to an inappropriate expression of the real behaviour of this type of buildings. We can therefore take advantage of the presence of these walls in the modeling process to increase the capacity of these buildings when they are exposed to seismic loadings.

Based on all of the above, we can say that these walls play a vital role in guiding the seismic behaviour of reinforced concrete buildings.

In general, it can be said that modeling infill walls by entering them directly into the design processes, can add additional strength and stiffness to the building that can reduce the losses caused by earthquakes. From there, we can take advantage of these walls to increase the efficiency of the building to dissipate the earthquake energy.

From this point of view, it has become imperative for all researchers, designers, as well as all those interested in this field, to unite their efforts to emerge a simulation better than what is available through a more accurate study based on experiments and as well as numerical analysis software.

We are in the process of using non-linear analysis methods for further study of this type of building, which has spread widely in various countries around the world.

We also try, in collaboration with many specialists in this field, to make contributions, albeit simple, within the framework of the preservation of urban heritage, in particular, what was carried out before the emergence of new simulation techniques, by studying its behaviour through innovative methods so that it can adapt to expected earthquakes and does not suffer significant damage, which can lead to its collapse.

Finally, all efforts must be focused on the linear and non-linear dynamic analysis, of the constituent elements of the masonry infill wall, being represented in a more precise and detailed way, so that specialists and researchers in this field can come closer to the real behaviour of these buildings to seismic loadings.

\section{ACKNOWLEDGEMENTS}

I would like to extend my sincere thanks to the people in charge of the Materials and Construction Processes Laboratory, Faculty of Sciences and Technology, University of Mostaganem, Algeria. Who with their help we have done many types of research. Through this laboratory, we were able to conduct many simulations and analyze results.

\section{REFERENCES}

[1] I. Fabio and D. Trapani, "Masonry infilled RC frames: Experimental results and development of Dottorato di Ricerca in Ingegneria delle Strutture - XXIV Ciclo Masonry infilled RC frames : Experimental results and development of predictive techniques for the assessment of seismic response Tesi di Dottorato di," no. September, 2014.

[2] F. Christiana, N. Kyriakides, and E. Georgiou, "FINITE ELEMENT MODEL OF MASONRY-INFILLED RC FRAME FINITE ELEMENT MODEL OF MASONRY-INFILLED RC FRAME," no. July, 2019.

[3] T. Nicola, C. Leandro, C. Guido, and S. Enrico, "Masonry infilled frame structures: State-of-the-art review of numerical modeling," Earthq. Struct., vol. 8, no. 3, pp. 733-759, 2015.

[4] K. M. Dolatshahi and A. J. Aref, "Two-dimensional computational framework of meso-scale rigid and line interface elements for masonry structures," Eng. Struct., vol. 33, no. 12, pp. 3657-3667, 2011.

[5] A. J. Aref and K. M. Dolatshahi, "A three-dimensional cyclic meso-scale numerical procedure for simulation of unreinforced masonry structures," Comput. Struct., vol. 120, pp. 9-23, 2013. 
[6] Q. P. G. Asteris, "Data in Brief The FP4026 Research Database on the fundamental period of RC in fi lled frame structures," Data Br., vol. 54, pp. 2-7, 2016.

[7] C. Z. Chrysostomou and P. G. Asteris, "On the in-plane properties and capacities of infilled frames," Eng. Struct., vol. 41, pp. 385-402, 2012.

[8] C. A. Filippou, N. C. Kyriakides, and C. Z. Chrysostomou, "The Open Construction \& Building Numerical Modeling of Masonry-infilled RC Frame Abstract :," pp. 135-148, 2019.

[9] C. A. Filippou, C. Z. Chrysostomou, and N. C. Kyriakides, "NUMERICAL MODELING OF MASONRY-INFILLED RC FRAME STRENGTHENED WITH TRM," pp. 3114-3128, 2019.

[10] P. G. Asteris, D. M. Cotsovos, C. Z. Chrysostomou, A. Mohebkhah, and G. K. Al-Chaar, "Mathematical micromodeling of infilled frames: state of the art," Eng. Struct., vol. 56, pp. 1905-1921, 2013.

[11] S. Engineering et al., "Modeling of the lateral stiffness of masonry infilled steel moment-resisting frames Modeling of the lateral stiffness of masonry infilled steel moment - resisting frames," no. May, 2019.

[12] P. G. Asteris, "Finite element micro-modeling of infilled frames," Electron. J. Struct. Eng., vol. 8, no. 8, pp. 1-11, 2008.

[13] L. Design, P. G. Asteris, C. C. Repapis, and E. V Repapi, "Fundamental period of infilled reinforced concrete frame structures," vol. 2479, no. September, 2016.

[14] R. D. E. Conception, E. T. D. E. Calcul, and D. E. S. Maconneries, C 2.45 regles de conception et de calcul des maconneries. .

[15] F. Sap, "CSi Analysis Reference Manual CSI Anal y sis Reference Manual."

[16] R. D. E. Conception, E. T. D. E. Calcul, D. E. S. Structures, and E. N. Beton, "Regles de conception et de calcul des structures en beton arme c.b.a.93."

[17] A. Earthquake, R. Regulations, R. Parasismiques, A. Rpa, A. Earthquake, and R. Regulations, "I g e ri a," pp. 1-39, 2008.

[18] "SeismoStruct User Manual 2018," 2018.

[19] D. Concept, "Rapport de mission République Algérienne Démocratique et Populaire," 2003. 